УДК 351:629.78]+348.](477)

DOI: 10.34132/PARD2020.08.06

\title{
НОРМАТИВНО-ПРАВОВЕ ЗАБЕЗПЕЧЕННЯ ДЕРЖАВНОГО РЕГУЛЮВАННЯ КОСМІЧНОЇ ГАЛУЗІ УКРАЇНИ
}

Псюк M.O., здобувач, Державний університет «Житомирська політехніка», м. Житомир, Україна.

Сергіенко Л.В., канд. наук 3 держ. упр., доцент, Державний університет «Житомирська політехніка», м. Житомир, Україна.

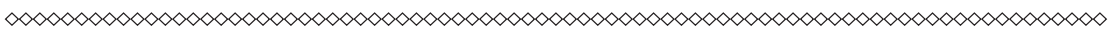

У статті досліджується законодавче підгрунтя державного регулювання космічної галузі Украӥни иляхом аналізу нормативно-правових актів, щзо регулюють дану сферу. У прочесі дослідження охарактеризовано ключові особливості нормативно-правової бази космічної галузі Украӥни, розглянуто сутність поняття державного регулювання космічної діяльності. Автором виділено окремо поняття державного управління космічною діяльністю, наголошуючи, що державне регулювання та управління космічною діяльністю має певні спільні риси та відмінності, а безпосередньо державне управління космічною діяльністю - ие вид організачійної діяльності держави, щчо полягає в сукупності засобів, методів, за допомогою яких органи публічної адміністрачії здійснюють владний вплив на суб' єктів космічної діяльності з метою забезпечення публічних інтересів.

Визначено щуо відповідальними за космічну політику стали, з одного боку, Мінекономіки - формування космічної політики, $і$ ДКА України у частині реалізація космічної політики, - з другого. Унаслідок перерозподілу космічних повноважень досі иілісний правовий механізм державного регулювання космічною діяльністю де-факто розпорошується між двома державними органами.

Констатовано щзо Украӥна є повноправним суб'єктом міжна- 
«Public Administration and Regional Development»

https://pard.mk.ua/index.php/journal

родного космічного права, приєднавщись до основоположних актів у сфері дослідження та використання космічного простору, прийнятих в рамках ООН та членом міжнародних організацій, які координують космічну діяльність.

На основі проведеного аналізу визначено ряд недоліків у нормативно-правовому забезпеченні державного регулювання космічної галузі України та запропоновано напрями їх усунення.

Ключові слова: державне регулювання, космічна галузь, нормативно-правове забезпечення галузі.

Постановка проблеми у загальному вигляді. В сучасному світі соціально-економічна та військово-політична успішність і конкурентоспроможність держави багато в чому залежить від наявності та рівня розвитку високотехнологічних галузей, які здатні забезпечувати основу для технологічного лідерства та довгострокові стратегічні переваги в умовах глобального світу. Однією з таких галузей $\epsilon$ космічна галузь, яка зосереджує в собі передові науково-технічні розробки та є драйвером росту для високотехнологічного сектору економіки. Тому законодавче забезпечення з метою проведення виваженої державної політики та ефективного державного регулювання космічної галузі є одним з важливих питань для забезпечення сталого розвитку галузі.

Аналіз досліджень і публікацій. Проблемним питанням нормативно-правового регулювання, державної політики та державного регулювання космічної діяльності присвячено праці таких науковців, як: Ю. Алєксєєв, В. Горбулін, Ю. Шемшученко, В. Семеняка, О. Джур, Л. Сорока та ін.

Формулювання цілей статті (постановка завдання). Метою даного дослідження $є$ аналіз законодавчого підгрунтя державного регулювання космічної галузі України та визначення напрямів його вдосконалення.

Виклад основного матеріалу дослідження. Космічна діяльність в Україні здійснюється відповідно до основного рамкового закону, який регулює сферу космічної діяльності - Закону України «Про космічну діяльність» [5], Закону України «Про державну під472 
Нормативно-правове забезпечення державного регулювання космічної галузі Украӥни тримку космічної діяльності» [4], а також указів Президента України, постанов Кабінету Міністрів України, міжнародних договорів та низки інших нормативно-правових актів.

Законом України «Про космічну діяльність» [5] визначено основні поняття та терміни космічної галузі. Так, відповідно до закону, космічна діяльність - це наукові космічні дослідження, використання космічного простору, розроблення, виробництво, ремонт та технічне обслуговування, випробування, експлуатація, управління об’єктами космічної діяльності (у тому числі їх агрегатами та складовими частинами), забезпечення запуску, запуск та повернення космічних апаратів, їх складових частин з космічного простору на землю. Також законом визначені об'єкти та суб'єкти космічної діяльності:

- об'єкти космічної діяльності (космічна техніка) - це матеріальні предмети штучного походження, що проектуються, виготовляються та експлуатуються як у космічному просторі (космічний сегмент, космічна інфраструктура), так і на поверхні Землі (наземний сегмент, наземна інфраструктура) з метою дослідження та використання космічного простору;

- суб'єкти космічної діяльності - підприємства, установи та організації будь-якої форми власності та організаційно-правової форми, в тому числі міжнародні та іноземні, які здійснюють космічну діяльність.

Що стосується розгляду сутності поняття державного регулювання космічної діяльності в науковій літературі, то різні автори дещо по різному розглядають дане поняття. Наприклад О. Джур визначає, що державне регулювання підприємств космічної галузі - це програма відповідальності, що реалізує завдання соціально-економічного та наукового прогресу держави, зростанню добробуту громадян через виконання своєї місії підприємствами космічної галузі, із наданням державою необхідних ресурсів та заходів, які дозволять здійснити синтез, поєднання минулого, теперішнього, майбутнього, створення нової реальності більш досконалого світу, де врівноважена духовна та матеріальна складова існування людства [1, с. 4]. Л. Сорока зазначає, що державне ISSN 2616-6216. Publ. upr. reg. rozvit. 2020, 8: 471-495 473 
«Public Administration and Regional Development»

https://pard.mk.ua/index.php/journal

регулювання космічної діяльності - це вид організаційної діяльності держави, що полягає в сукупності засобів, методів, за допомогою яких державні або недержавні організації, яким держава делегувала регуляторні повноваження, встановлюють принципи, норми, правила для космічної діяльності та здійснюють контроль за такою діяльністю з метою задоволення публічних та приватних інтересів $[18$, с.197]. При цьому автор виділяє окремо поняття державного управління космічною діяльністю, наголошуючи, що державне регулювання та управління космічною діяльністю має певні спільні риси та відмінності, а безпосередньо державне управління космічною діяльністю - це вид організаційної діяльності держави, що полягає в сукупності засобів, методів, за допомогою яких органи публічної адміністрації здійснюють владний вплив на суб'єктів космічної діяльності з метою забезпечення публічних інтересів [18, c. 197].

Відповідно до статті 5 Закону України «Про космічну діяльність» [5], державне регулювання та управління у сфері космічної діяльності в Україні здійснюються шляхом:

- законодавчого встановлення основних принципів, норм і правил космічної діяльності;

- розробки концептуальних основ державної політики у галузі дослідження і використання космічного простору в мирних цілях та в інтересах безпеки держави;

- формування Загальнодержавної цільової науково-технічної космічної програми України;

- планування та фінансування космічної діяльності за рахунок коштів Державного бюджету України, а також сприяння залученню інших джерел фінансування, не заборонених чинним законодавством України;

- цільової підготовки кадрів за рахунок Державного бюджету України;

- запровадження ліцензування такої діяльності;

- контролю за здійсненням зовнішньоекономічної діяльності суб'єктами космічної діяльності [5].

Історія української космічної програми бере свій початок від 
Нормативно-правове забезпечення держсавного регулювання космічної галузі Украйни 29 лютого 1992 року, коли Указом Президента України Л. Кравчука [20] було утворено Національне космічне агентство України (НКАУ), яке 9 грудня 2010 р. перейменовано в Державне космічне агентство України (ДКА) [19]. В перші місяці Незалежності України визначалися головні вектори розвитку держави, країни-стратегічні партнери та структура влади. Одними 3 основних питань, які обговорювалися в космічній сфері, був пошук шляхів збереження та розвитку ракетно-космічного комплексу, створення власної структури управління підприємствами, перегляд їх спеціалізації та налагодження ефективних коопераційних зв'язків. Особливим питанням було формування космічної політики держави. Для вирішення цих завдань й було утворено НКАУ із статусом центрального органу виконавчої влади [6].

Державне космічне агентство України - центральний орган виконавчої влади, на який покладено завдання реалізації державної політики у сфері космічної діяльності в Україні [13]. Відповідно до Положення, в рамках покладених на нього завдань, ДКА, здійснює заходи в напрямку законодавчого забезпечення державного регулювання галузі, зокрема:

- узагальнює практику застосування законодавства 3 питань, що належать до сфери діяльності ДКА, розробляє пропозиції щодо його вдосконалення, готує проекти законодавчих актів, актів Президента України, Кабінету Міністрів України та в установленому порядку подає їх Міністру розвитку економіки, торгівлі та сільського господарства;

- погоджує проекти законів, інших актів законодавства, які надходять на погодження від інших центральних органів виконавчої влади, готує в межах повноважень, передбачених законом, висновки i пропозиції до проектів законів, інших актів законодавства, які подаються на розгляд Кабінету Міністрів України, та проектів законів, внесених на розгляд Верховної Ради України іншими суб'єктами права законодавчої ініціативи;

- забезпечує створення та експлуатацію наземного і космічного сегментів супутникових систем зв'язку, мовлення та дистанційного зондування Землі, контролю і аналізу космічної обстановки, коорISSN 2616-6216. Publ. upr. reg. rozvit. 2020, 8: 471-495 475 
«Public Administration and Regional Development»

https://pard.mk.ua/index.php/journal

динатно-часового та навігаційного забезпечення;

- вживає заходів до оперативного виявлення джерел небезпек та сприяє в межах своїх повноважень досягненню належного рівня надійності та ефективності систем державного управління в особливий період;

- здійснює міжнародне співробітництво та реалізацію зовнішньої політики у межах своєї компетенції у сфері космічної діяльності;

- здійснює заходи щодо розроблення та функціонування Системи сертифікації космічної техніки України (УкрССКТ), забезпечує суб'єкти космічної діяльності в Україні необхідною нормативною документацією;

- бере участь у здійсненні заходів щодо адаптації законодавства України до законодавства Свропейського Союзу у сфері космічної діяльності;

- забезпечує разом з міністерствами та іншими центральними органами виконавчої влади експлуатацію, підтримку та вдосконалення об'єктів космічної діяльності;

- забезпечує ефективне використання науково-технічного i виробничого потенціалу підприємств, установ та організацій, що належать до сфери його управління, та створює умови для впровадження космічних технологій у виробництво конкурентоспроможної продукції для потреб внутрішнього та зовнішнього ринку;

- забезпечує утилізацію твердого ракетного палива міжконтинентальних балістичних ракет РС-22;

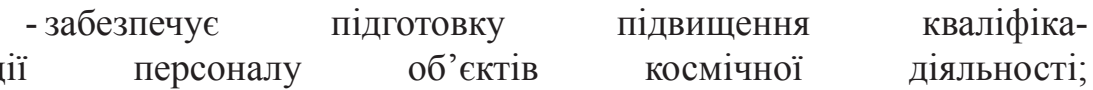

подає пропозиції до проекту державного замовлення на підготовку фахівців у сфері космічної діяльності;

- забезпечує дотримання вимог законодавства у сфері охорони праці, цивільного захисту, техногенної та пожежної безпеки, охорони навколишнього природного середовища на підприємствах, в установах та організаціях, що належать до сфери його управління;

- веде Державний реєстр унікальних об'єктів космічної діяльності, здійснює державний нагляд за їх станом і використанням, вживає заходів для їх підтримки; 
Нормативно-правове забезпечення державного регулювання космічної галузі Украйни

- здійснює реєстрацію космічної техніки;

- здійснює моніторинг та веде банк даних геофізичних спостережень і забезпечує його взаємодію з Національним центром даних системи сейсмічних спостережень і підвищення безпеки проживання населення в сейсмонебезпечних регіонах;

- здійснює державний нагляд за дотриманням вимог безпеки космічної діяльності;

- здійснює контроль за дотриманням вимог міжнародних договорів України про обмеження і заборону випробувань ядерної зброї, випробувань ядерної зброї на іноземних випробувальних полігонах і здійсненням ядерних вибухів у мирних цілях;

- здійснює функції національного контактного пункту з питань дотримання положень Гаазького кодексу поведінки проти розповсюдження балістичних ракет;

- забезпечує згідно із законодавством функції страхувальника під час проведення обов' язкового страхування об' єктів космічної діяльності (космічна інфраструктура), які є власністю України, а також обов'язкового страхування відповідальності;

- здійснює розгляд звернень громадян 3 питань, пов'язаних 3 діяльністю ДКА, підприємств, установ та організацій, що належать до сфери його управління;

- інформує громадськість про свою діяльність, забезпечує взаємодію з інститутами громадянського суспільства та врахування громадської думки під час формування та реалізації державної політики у сфері космічної діяльності;

- сприяє розвитку соціального діалогу, проводить консультації iз всеукраїнськими об'єднаннями профспілок і всеукраїнськими об'єднаннями організацій роботодавців щодо проектів законів, інших нормативно-правових актів 3 питань розроблення та реалізації державної політики у сфері трудових відносин, оплати праці, охорони праці, соціального захисту;

- організовує наукову, науково-технічну, інвестиційну, інформаційну, видавничу діяльність, пропагування досягнень і передового досвіду, сприяє створенню і впровадженню сучасних інформаційних технологій та комп’ютерних мереж у сфері космічної діяльності; 
- здійснює інші повноваження, визначені законом [13].

- Як зазначають Ю. Шемшученко і В. Семеняка [22, с. 13], основоположне значення для подальшого розвитку космічної галузі має забезпечення ефективного державного управління космічною діяльністю. Єдиним компетентним державним органом, який забезпечував формування і реалізацію космічної політики, був центральний орган з питань космічної діяльності - ДКА України. Однак у 2012 р. зазначена норма Закону України «Про космічну діяльність» зазнала істотного корегування. Нею передбачається розмежування органу державного управління: на орган управління, що забезпечує формування космічної політики і орган управління, який забезпечує реалізацію космічної політики. Таким чином, фактично ДКА України позбавлене функції формування космічної політики, залишилось тільки забезпечення їі реалізації.

4 грудня 2019 р. Постановою Кабінету Міністрів України №1072 [12] внесено зміни у Положення про Міністерство розвитку економіки торгівлі та сільського господарства України (далі - Мінекономіки) та у Положення про Державне космічне агентство України. Відповідно до цих змін, Мінекономіки є головним органом у системі центральних органів виконавчої влади, що забезпечує формування та реалізацію державної політики у сфері космічної діяльності, а одним з основних завдань міністерства додано забезпечення формування та реалізації державної політики у сфері космічної діяльності. В сфері космічної діяльності Мінекономіки відповідно до покладених на нього завдань:

- розробляє концептуальні основи державної політики у сфері дослідження та використання космічного простору в мирних цілях та інтересах держави;

- забезпечує організацію космічної діяльності в Україні та під юрисдикцією України поза ії межами;

- розробляє разом 3 міністерствами, іншими центральними органами виконавчої влади та Національною академією наук Загальнодержавну цільову науково-технічну космічну програму та забезпечує їі виконання;

- $є$ державним генеральним замовником науково-дослідних робіт 
Нормативно-правове забезпечення державного регулювання космічної галузі Украйни

3 дослідження та використання космічного простору, науково-дослідних і дослідно-конструкторських робіт з проектування, виготовлення та випробування космічної техніки, зокрема міжнародних космічних проектів;

- забезпечує суб’єктів космічної діяльності в Україні необхідною нормативною документацією;

- здійснює координацію та контроль за зовнішньоекономічною діяльністю в космічній сфері на відповідність законодавству та міжнародним договорам України;

- надає підтримку щодо підготовки та реалізації міжнародних проектів у сфері дослідження та використання космічного простоpy;

- організовує співробітництво України 3 іншими державами та міжнародними організаціями в космічній сфері, а також забезпечує збереження і розвиток наявних міжнародних зв'язків у сфері космічної діяльності;

- вживає заходів, спрямованих на вдосконалення зовнішньоекономічних відносин України з іншими державами у сфері космічної діяльності;

- затверджує порядок діяльності представництв генерального замовника - ДКА з контролю якості та прийняття космічної техніки та іншої продукції [12].

Згідно вказаної постанови ДКА є центральним органом виконавчої влади, діяльність якого спрямовується і координується Кабінетом Міністрів України через Міністра розвитку економіки, торгівлі та сільського господарства та який реалізує державну політику у сфері космічної діяльності.

У 2019 р. наказами Мінекономіки повноваження щодо формування космічної політики закріплено за Управлінням координації космічної діяльності у складі департаменту стратегічного розвитку сектору оборонитабезпекиМінекономіки[9], деутвореновідділекономікисфери космічної діяльності та відділ аналізу супроводження міжнародних проектів у сфері космічної діяльності [10]. Відтак відповідальними за космічну політику стали, з одного боку, Мінекономіки - формування космічної політики, і ДКА України у частині реалізація космічної ISSN 2616-6216. Publ. upr. reg. rozvit. 2020, 8: 471-495 
«Public Administration and Regional Development»

https://pard.mk.ua/index.php/journal

політики, - 3 другого. Унаслідок перерозподілу космічних повноважень досі цілісний правовий механізм державного регулювання космічною діяльністю де-факто розпорошується між двома державними органами в умовах відсутності правового алгоритму координації їхніх спільних дій [22, с. 13].

У 2019 році парламентом було ухвалено Закон України «Про внесення змін до деяких законів України щодо державного регулювання космічної діяльності» № 143-IX [3], яким встановлюються важливі нововведення для космічної галузі 3 метою підвищення іiі інвестиційної привабливості, формування конкурентного середовища для суб'єктів космічної діяльності різних форм власності. Документом передбачається, що суб'єктами космічної діяльності можуть бути підприємства, установи та організації будь-якої форми власності та організаційно-правової форми. Закон також визначає основні засади космічної діяльності в Україні, зокрема: державна підтримка комерціалізації космічної діяльності та залучення інвестицій у космічну галузь України; відкриття космосу для громадян та юридичних осіб і можливість вільно досліджувати та використовувати космос, включно 3 використанням космічного простору та ресурсів, що містяться в ньому; еволюційність розвитку та послідовність реформування державної політики у галузі дослідження та використання космічного простору; ефективне використання науково-технічного потенціалу України, можливостей, які надає космічна діяльність, в інтересах національної економіки, науки, безпеки держави і в комерційних цілях; сприяння міжнародній співпраці, збереження та розвиток наявних міжнародних зв'язків у космічній галузі 3 урахуванням національних інтересів.

Згідно із законом, суб'єкти космічної діяльності України приватної форми власності, які мають намір здійснювати космічну діяльність, повинні подати центральному органу виконавчої влади, що забезпечує формування і реалізацію державної політики у сфері космічної діяльності, декларацію про провадження господарської діяльності у сфері космічної діяльності. Порядок подання такої декларації встановлює Кабінет Міністрів України. 
Нормативно-правове забезпечення державного регулювання космічної галузі Украӥни

Закон також передбачає, що здійснення окремих видів космічної діяльності провадиться на підставі дозволу. Дозволи надаються на здійснення таких видів космічної діяльності: випробування (крім комп'ютерних) ракет-носіїв, включно з їхніми агрегатами та складовими частинами, і космічних апаратів; запуски ракет-носіїв та/або космічних апаратів; управління космічними апаратами на навколоземній орбіті або в космічному просторі; повернення космічних апаратів та/або їхніх складових частин, що повертаються, 3 навколоземної орбіти або космічного простору на Землю.

Видача (відмова у видачі, переоформлення, анулювання) дозволу на здійснення окремих видів космічної діяльності здійснюється центральним органом виконавчої влади, що реалізує державну політику у сфері космічної діяльності, на безоплатній основі відповідно до цього закону. Подавати заяву на одержання (переоформлення, анулювання) дозволу можна у паперовій або електронній формі на вибір заявника у порядку, встановленому Законом України «Про дозвільну систему у сфері господарської діяльності».

Загалом, прийняття зазначених змін до основного «космічного закону» покликане сприяти збереженню науково-технологічного потенціалу космічної галузі України та залученню приватного капіталу до новітніх технологічних розробок.

В 2020 році Урядом, на реалізацію розглянутого нами Закону України «Про внесення змін до деяких законів України щодо державного регулювання космічної діяльності», були прийняті відповідні рішення, які зняли заборону на провадження космічної діяльності приватними підприємствам. Постанова КМУ «Про затвердження Порядку видачі (відмови у видачі, анулювання) дозволів на провадження окремих видів космічної діяльності» №197 від 26.02.2020p. [14] передбачає, що відтепер суб'єкти господарювання приватної форми власності, можуть отримати дозвіл на здійснення таких видів космічної діяльності:

1) випробування (окрім комп'ютерних) ракет-носіїв, в тому числі їх агрегатів та складових частин і космічних апаратів;

2) запуски ракет-носіїв та/або космічних апаратів;

3) управління космічними апаратами на навколоземній орбіті або в космічному просторі; 
«Public Administration and Regional Development»

https://pard.mk.ua/index.php/journal

4) повернення космічних апаратів та/або їх складових частин, що повертаються 3 навколоземної орбіти або космічного простору на Землю.

Видача (відмова у видачі, анулювання) відповідного дозволу здійснюється ДКА на безоплатній основі.

Постанова КМУ «Про затвердження Порядку подання декларації про провадження господарської діяльності у сфері космічної діяльності» №198 від 26.02.2020p. [15] визначає процедуру подання декларації про провадження господарської діяльності у сфері космічної діяльності, що дає право суб'єкту господарювання провадити господарську діяльність у сфері космічної діяльності. приватні підприємства, які мають намір здійснювати космічну діяльність, мають подати центральному органу виконавчої влади, що забезпечує реалізацію державної політики у сфері космічної діяльності, декларацію про провадження господарської діяльності. Така декларація $є$ інструментом входження на ринок космічних технологій для суб'єктів космічної діяльності приватної форми власності.

Відповідно до статті 7 Закону України «Про космічну діяльність» [5], космічна діяльність в Україні здійснюється на основі Загальнодержавної цільової науково-технічної космічної програми України, яка розробляється на п’ять років і затверджується Верховною Радою України за поданням Кабінету Міністрів України. За роки незалежності в Україні було реалізовано 5 космічних програм [6]. Періоди виконання та основні здобутки космічних програм викладено в таблиці 1.

Таблиця 1

Космічні програми України за період 1993-2017 рр.[6]

\begin{tabular}{|c|c|l|}
\hline $\begin{array}{c}\text { Космічна } \\
\text { програма }\end{array}$ & $\begin{array}{c}\text { Роки } \\
\text { виконання }\end{array}$ & \multicolumn{1}{|c|}{ Основні здобутки } \\
\hline $\begin{array}{c}\text { Перша космічна } \\
\text { програма }\end{array}$ & $1993-1997$ & $\begin{array}{l}\text { Протягом 1993-1997 pp. було } \\
\text { виготовлено та запущено 32 ракети- } \\
\text { носія та 13 космічних апаратів } \\
\text { української розробки. }\end{array}$ \\
\hline
\end{tabular}


Нормативно-правове забезпечення державного регулювання космічної галузі України продовження таблииі 1

\begin{tabular}{|c|c|c|}
\hline $\begin{array}{c}\text { Друга космічна } \\
\text { програма }\end{array}$ & 1998-2002 & 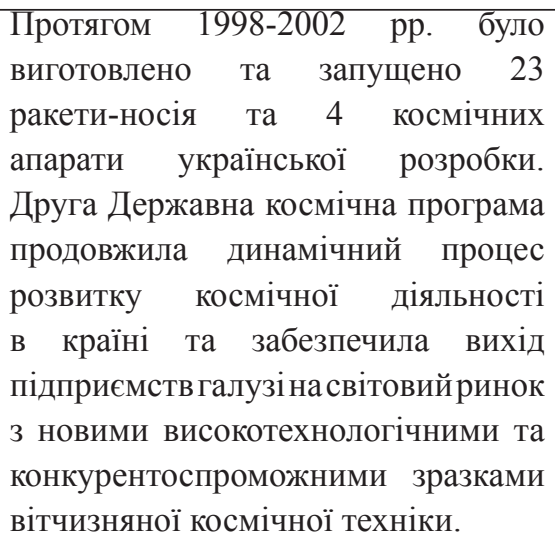 \\
\hline $\begin{array}{c}\text { Третя космічна } \\
\text { програма }\end{array}$ & 2003-2007 & $\begin{array}{l}\text { Було забезпечено } 28 \text { пусків ракет- } \\
\text { носіїв українського виробництва, } \\
3 \text { них } 16 \text { пусків за програмою } \\
\text { «Морський старт» та } 7 \text { пусків за } \\
\text { програмою «Дніпро». Протягом } \\
2003-2007 \text { рр. було виготовлено } \\
\text { та запущено } 5 \text { космічних апаратів } \\
\text { власної розробки. }\end{array}$ \\
\hline $\begin{array}{c}\text { Четверта космічна } \\
\text { програма }\end{array}$ & 2008-2012 & $\begin{array}{l}\text { Протягом 2008-2012 pp. було } \\
\text { запущено } 27 \text { ракет-носіїв, створених } \\
\text { за участю України, та } 1 \text { космічний } \\
\text { апарат власної розробки. }\end{array}$ \\
\hline $\begin{array}{c}\text { П’ята космічна } \\
\text { програма }\end{array}$ & 2013-2017 & $\begin{array}{l}\text { Всього, протягом 2013-2017 pp., } \\
\text { було запущено } 27 \text { ракет-носіїв, } \\
\text { створених за участю України. } \\
\text { Реалізація п’ятої Державної } \\
\text { космічної програми проходила в } \\
\text { умовах втрати частини традиційних } \\
\text { ринків, нестабільного бюджетного } \\
\text { фінансування, а також частих змін } \\
\text { керівництва агентства та окремих } \\
\text { підприємств галузі. }\end{array}$ \\
\hline
\end{tabular}


«Public Administration and Regional Development» https://pard.mk.ua/index.php/journal

На жаль, за роки реалізації загальнодержавних цільових науково-технічних космічних програм України характерною їхньою особливістю було хронічне недофінансування, що стало причиною зриву багатьох космічних програм та міжнародних коопераційних проектів. В таблиці 2 представлено аналіз фінансування Загальнодержавної цільової науково-технічної космічної програми України на 2013-2017 роки. Виконання програми фактично профінансовано із державного бюджету на суму 380 409,1 тис. грн., що становить 33,9 \% від першочергово передбаченого програмою.

Таблиця 2

Фінансування Загальнодержавної цільової науково-технічної космічної програми України на 2013-2017 рр.[ 2]

\begin{tabular}{|c|c|c|c|c|}
\hline \multirow[b]{2}{*}{$\begin{array}{c}\text { За } \\
\text { роками }\end{array}$} & \multicolumn{4}{|c|}{$\begin{array}{c}\text { Державний бюджет, тис. грн., } \\
\text { *інші джерела, тис. грн. (позабюджетні кошти отримані } \\
\text { підприємствами) }\end{array}$} \\
\hline & $\begin{array}{c}\text { Перед- } \\
\text { бачено } \\
\text { Програмою }\end{array}$ & $\begin{array}{c}\text { Затверджено } \\
\text { паспортом } \\
\text { бюджетної } \\
\text { Програми }\end{array}$ & $\begin{array}{l}\text { Фактично } \\
\text { профінан- } \\
\text { совано }\end{array}$ & $\begin{array}{c}\text { В \% до } \\
\text { передбаченого }\end{array}$ \\
\hline 2013 & $\begin{array}{rl}98 & 700,0 \\
389 & 000,0^{*}\end{array}$ & 98625,0 & $\begin{array}{c}25263,1 \\
1272351,0 *\end{array}$ & $\begin{array}{l}25,6 \\
327^{*}\end{array}$ \\
\hline 2014 & $\begin{array}{c}230700,0 \\
207000,0^{*}\end{array}$ & 10000,0 & $\begin{array}{c}67876,7 \\
850800,0 *\end{array}$ & $\begin{array}{l}29,4 \\
411 *\end{array}$ \\
\hline 2015 & $\begin{array}{c}335200,0 \\
258000,0^{*}\end{array}$ & 49400,0 & $\begin{array}{c}30300,3 \\
597532,1 *\end{array}$ & $\begin{array}{c}9,0 \\
231,6^{*}\end{array}$ \\
\hline 2016 & $\begin{array}{c}226900,0 \\
295000,0^{*}\end{array}$ & 223600,0 & $\begin{array}{c}176917,3 \\
750000,0^{*}\end{array}$ & $\begin{array}{c}78,0 \\
254,2 * \\
\end{array}$ \\
\hline 2017 & $\begin{array}{c}228500,0 \\
311000,0 *\end{array}$ & 81100,0 & $\begin{array}{c}80051,7 \\
1200000,0 *\end{array}$ & $\begin{array}{c}35,0 \\
385,8 *\end{array}$ \\
\hline $\begin{array}{c}\text { Разом } \\
\text { за } \\
\text { програ- } \\
\text { мою }\end{array}$ & $\begin{array}{c}1120000,0 \\
1460 \\
000,0 *\end{array}$ & 462725,0 & $\begin{array}{c}380409,1 \\
4670683,1 *\end{array}$ & $\begin{array}{c}33,9 \\
319,9 *\end{array}$ \\
\hline
\end{tabular}

На сьогоднішній день державна політика у сфері космічної діяльності реалізується у відповідності до Конщепщії реалізації 484 
Нормативно-правове забезпечення державного регулювання космічної галузі Украӥни державної політики у сфері космічної діяльності на період до 2032 року, яка схвалена розпорядженням Кабінет Міністрів України № 238 від 30 березня 2011 року [16]. В Концепції визначено, що забезпечення розвитку сучасних космічних технологій в Україні $\epsilon$ важливим чинником, що визначає стратегічне місце держави у світі. Проблемою, яка потребує розв'язання, є значна диспропорція між рівнем космічного потенціалу та його впливом на вирішення актуальних загальнодержавних і суспільних завдань. Основні причини виникнення проблеми пов'язані з тривалою відсутністю ефективної державної підтримки у сфері космічної діяльності, а також необхідністю реформування зазначеної сфери. Відповідно, окреслено напрями виконання Концепції:

- забезпечення розвитку космічних технологій та їх інтеграції до реального сектору національної економіки і сфери національної безпеки та оборони;

- одержання нових знань, підвищення науково-технічного потенціалу держави та освітнього рівня її громадян;

- удосконалення ракетно-космічної техніки та технологій іiї створення;

- реалізація ефективної промислової політики та модернізація виробництва;

- забезпечення комерціалізації космічної діяльності;

- поглиблення міжнародного співробітництва у сфері космічної діяльності [16].

Виконання концепції передбачає активну співпрацю ДКА з науковими установами та уповноваженими державними органами. На момент прийняття Концепції, іiі виконавцями, спільно з ДКА, були зазначені: Державне космічне агентство України, Міністерство закордонних справ України, Міністерство оборони України, Міністерство аграрної політики та продовольства України, Міністерство надзвичайних ситуацій України, Міністерство екології та природних ресурсів України, Національна академія наук України, Національна академія аграрних наук України, Державна інспекція сільського господарства України, Адміністрація Державної служби спеціального зв'язку та захисту інформації, 
«Public Administration and Regional Development»

https://pard.mk.ua/index.php/journal

Концепція визначає 20 річну космічну стратегію України i, відповідно до неї, ДКА розроблено індикативний План заходів щодо виконання Концепції реалізації державної політики у сфері космічної діяльності на період до 2032 року, який затверджено Розпорядженням Кабінету Міністрів України від 25 січня 2012 року № 48 [17]. В плані представлені основні напрями, етапи та очікувані результати виконання Концепції реалізації державної політики у сфері космічної діяльності на період до 2032 року. Детальний зміст та обсяги фінансування заходів Концепції визначатимуться п`ятирічними загальнодержавними цільовими науково-технічними космічними програмами (на 2013-2017, 2018-2022, 2023-2027, 2028-2032 роки) та іншими державними програмами, спрямованими на розвиток космічної діяльності. Варто зазначити, що відповідна програма на 2018-2022 роки поки не була затверджена, що справляє негативний вплив на розвиток галузі, оскільки відсутня можливість фінансування заходів космічної програми, власне, як і сам затверджений відповідною перелік таких заходів.

На виконання Указу Президента України від 12.01.2015 №5/2015 «Про Стратегію сталого розвитку «Україна-2020» [21] та Програми діяльності Кабінету Міністрів України, схваленої постановою Верховної Ради України від 11.12.2014 №26-VIII [11] 3 метою підвищення ефективності космічної діяльності України Наказом ДКА України від 21.05.2015 № 100 затверджено «Стратегію космічної діяльності України на період до 2022 року» [8]. Стратегія космічної діяльності України до 2022 року визначає проблеми, які потребують розв'язання, мету, шляхи реалізації та містить комплекс першочергових заходів, спрямованих на забезпечення розвитку космічної галузі.

Космічна галузь України, безумовно, є частиною світової глобальної аерокосмічної сфери, оскільки специфіка розвитку галузі передбачає широку науково-технічну та виробничу кооперацію, розвиток міжнародних програм та проектів. Міжнародне космічне співробітництво України регулюється цілою низкою нормативно-правових актів, які можна розділити на відповідні тематичні напрямки: 
Нормативно-правове забезпечення державного регулювання космічної галузі Украӥни

- багатостороннє співробітництво $з$ дослідження та використання космічного простору;

- двостороннє співробітництво України в сфері космічної діяльності;

- космічне співробітництво в рамках СНД;

- космічне співробітництво в межах міжнародних проектів і програм;

- міжнародне співробітництво в рамках міжнародних організацій 3 нерозповсюдження зброї масового ураження та експортного контролю.

Співробітництво України з іноземними державами у сфері дослідження та використання космічного простору в мирних цілях грунтується на чинному законодавстві України та міжнародних договорах, укладених з іноземними державами у космічній сфері.

Україна є повноправним суб'єктом міжнародного космічного права, приєднавшись до основоположних актів у сфері дослідження та використання космічного простору, прийнятих в рамках $\mathrm{OOH}$ та членом міжнародних організацій, які координують космічну діяльність, у тому числі: Комітету $\mathrm{OOH}$ із мирного використання космосу (COPUOS), Всесвітнього комітету із космічних досліджень (COSPAR), Міжагентського комітету з космічного сміття (IADS), Всесвітньої організації з супутникових досліджень Землі (CEOS), Міжнародної астронавтичної федерації (IAF). На сьогоднішній день підписано двосторонні міжнародні договори щодо співробітництва 3 космічними агентствами і відомствами Російської Федерації, Казахстану, США, Бразилії, Аргентини, Індії, Китаю, Ізраїлю, Туреччини та країн Свропейського Союзу [7].

Загалом, зважаючи на численність нормативно правових актів, що регулюють відносини в космічній галузі України, позитивним заходом могло бути проведення кодифікації національного космічного права, що дозволить забезпечити системність та узгодженість галузевого законодавства.

Висновки. Державне регулювання космічної діяльності в Україні потребує проведення виваженої стратегічної державної політики та ефективного нормативно-правового забезпечення гаISSN 2616-6216. Publ. upr. reg. rozvit. 2020, 8: 471-495 
«Public Administration and Regional Development»

https://pard.mk.ua/index.php/journal

лузі. Першочерговим завданням, яке потребує галузь, є прийняття відповідної загальнодержавної цільової науково-технічної космічної програми. Це дозволить закласти основи для подальшого розвитку, забезпечити належний рівень фінансування галузі, уможливить виконання галузевих програм і проектів.

У середньостроковій перспективі необхідне прийняття космічного кодексу, що систематизує галузеве законодавство та приведе його у відповідність сучасним викликам та реаліям космічної сфери, полегшить розвиток ефективної космічної екосистеми України.

\section{Стаття надійшла до редакції: 06.04.20}


Нормативно-правове забезпечення держсавного регулювання космічної галузі Украӥни

\section{REGULATORY AND LEGAL SUPPORT OF STATE REGULATION OF THE SPACE INDUSTRY OF UKRAINE}

Mykhaylo Psiuk, applicant, Zhytomyr Polytechnic State University Zhytomyr, Ukraine

Larysa Sergiienko, PhD in Public Administration, Zhytomyr Polytechnic State University Zhytomyr, Ukraine

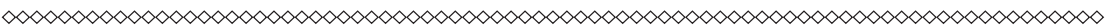

The article examines the legislative basis of state regulation of the space industry of Ukraine by analyzing the regulations governing this area. In the course of the research the key features of the regulatory framework of the space industry of Ukraine are characterized, the essence of the concept of state regulation of space activity is considered. Based on the analysis, a number of shortcomings in the regulatory and legal support of state regulation of the space industry of Ukraine are identified and directions for their elimination are proposed.

In today's world, the socio-economic and military-political success and competitiveness of the state largely depends on the availability and level of development of high-tech industries that can provide a basis for technological leadership and long-term strategic advantages in a global world. One such industry is the space industry, which concentrates advanced scientific and technical developments and is a driver of growth for the high-tech sector of the economy. Therefore, legislative support for a balanced state policy and effective state regulation of the space industry is one of the important issues to ensure the sustainable development of the industry.

Space activities in Ukraine are carried out in accordance with the main framework law governing the field of space activities - the Law of Ukraine "On Space Activities", the Law of Ukraine "On State Support of Space Activities", as well as decrees of the President of Ukraine, resolutions of the Cabinet of Ministers, international treaties and a number of other regulations.

The Law of Ukraine "On Space Activities" defines the basic concepts and terms of the space industry. Thus, according to the law, space ISSN 2616-6216. Publ. upr. reg. rozvit. 2020, 8: 471-495 
«Public Administration and Regional Development»

https://pard.mk.ua/index.php/journal

activities - space research, use of outer space, development, production, repair and maintenance, testing, operation, management of space activities (including their units and components), launch and return of spacecraft, their components from outer space to earth.

The State Space Agency of Ukraine is the central executive body tasked with implementing state policy in the field of space activities in Ukraine.

According to Article 7 of the Law of Ukraine "On Space Activities", space activities in Ukraine are carried out on the basis of the National Targeted Scientific and Technical Space Program of Ukraine, which is developed for five years and approved by the Verkhovna Rada of Ukraine. Unfortunately, over the years of implementation of national targeted scientific and technical space programs of Ukraine, their characteristic feature was chronic underfunding, which led to the failure of many space programs and international cooperation projects.

To date, state policy in the field of space activities is implemented in accordance with the Concept of implementation of state policy in the field of space activities for the period up to 2032.

The strategy of space activity of Ukraine until 2022 identifies the problems that need to be solved, the goal, ways of implementation and contains a set of priority measures aimed at ensuring the development of the space industry.

The space industry of Ukraine, of course, is part of the global global aerospace sphere, as the specifics of the development of the industry involves extensive scientific, technical and industrial cooperation, development of international programs and projects. Ukraine's international space cooperation is regulated by a number of regulations

In general, given the number of normative legal acts regulating relations in the space industry of Ukraine, a positive measure could be the codification of national space law, which will ensure the system and consistency of sectoral legislation.

State regulation of space activities in Ukraine requires a balanced strategic state policy and effective regulatory support for the industry. The priority that the industry needs is the adoption of an appropriate 
Нормативно-правове забезпечення державного регулювання космічної галузі Украйни

nationwide targeted scientific and technical space program. This will ensure an adequate level of funding for the industry and lay the foundations for further development. In the medium term, it is necessary to adopt a space code that systematizes sectoral legislation and facilitates the development of an effective space ecosystem in Ukraine.

Keywords: state regulation, space industry, regulatory support of the industry.

\section{Received: 06.04.20}

\section{References}

1. Dzhur, O.Ie. (2015). Derzhavne rehuliuvannia pidpryiemstv kosmichnoi haluzi Ukrainy: novi realii ta vyklyky [State regulation of space industry enterprises in Ukraine: new realities and challenges]. Efektyvna ekonomika - Efficient economy, 1. Retrieved from http://www.economy.nayka. com.ua/?op=1\&z=3748 [in Ukrainian].

2. Istoriia. Sait Derzhavnoho kosmichnoho ahentstva Ukrainy [History. Website of the State Space Agency of Ukraine]. www.nkau.gov.ua. Retrieved from https://www.nkau.gov.ua/ua/dka-ukrainy/istoriia [in Ukrainian].

3. Mizhnarodna diialnist. Sait Derzhavnoho kosmichnoho ahentstva Ukrainy [International activities. Website of the State Space Agency of Ukraine]. www.nkau.gov.ua. Retrieved from https://www.nkau.gov.ua/ua/ activity/mizhnarodna-diialnist [in Ukrainian].

4. Nakaz Derzhavnoho kosmichnoho ahentstva Ukrainy vid 21.05.2015 No 100 «Stratehiia kosmichnoi diialnosti Ukrainy na period do 2022 roku» [Order of the State Space Agency of Ukraine dated 21.05.2015 No 100 «Strategy of space activities of Ukraine for the period up to 2022»]. www.nkau.gov.ua. Retrieved from https://www.nkau.gov.ua/ua/activity/stratehiia-do-2022-roku [in Ukrainian].

5. Nakaz Ministerstva ekonomichnoho rozvytku i torhivli Ukrainy «Pro zatverdzhennia Polozhennia pro upravlinnia koordynatsii kosmichnoi diialnosti departamentu stratehichnoho rozvytku sektoru oborony ta bezpeky» vid 27.02.2019 r. No 328. [Order of the Ministry of Economic Development and Trade of Ukraine «On approval of the Regulations on the management of space ISSN 2616-6216. Publ. upr. reg. rozvit. 2020, 8: 471-495 
«Public Administration and Regional Development»

https://pard.mk.ua/index.php/journal

coordination of the Department of Strategic Development of the Defense and Security Sector» dated 27.02.2019 No 328]. zakon.rada.gov.ua. Retrieved from https://zakon.rada.gov.ua/rada/show/v0328731-19 [in Ukrainian].

6. Nakaz Ministerstva ekonomichnoho rozvytku i torhivli Ukrainy «Pro zatverdzhennia polozhen pro strukturni pidrozdily upravlinnia koordynatsii kosmichnoi diialnosti departamentu stratehichnoho rozvytku sektoru oborony ta bezpeky» vid 13.08.2019 r. No 1384. [Order of the Ministry of Economic Development and Trade of Ukraine «On approval of regulations on structural units of the Department for Coordination of Space Activities of the Department of Strategic Development of the Defense and Security Sector» dated 13.08.2019 No 1384]. zakon.rada.gov.ua. Retrieved from https://zakon.rada.gov.ua/rada/ show/v1384731-19 [in Ukrainian].

7. Postanova Kabinetu Ministriv Ukrainy vid 04 hrudnia 2019 r. No 1072 «Pro vnesennia zmin ta vyznannia takymy, shcho vtratyly chynnist, deiakykh aktiv Kabinetu Ministriv Ukrainy» [Resolution of the Cabinet of Ministers of Ukraine of December 4, 2019 No 1072 «On Amendments and Repeal of Certain Acts of the Cabinet of Ministers of Ukraine»]. www.kmu.gov.ua. Retrieved from https://www.kmu.gov.ua/npas/pro-vnesennya-zmin-ta-viznannya-takimishcho-vtratili-chinnist-deyakih-aktiv-kabinetu-ministriv-ukrayini-1072-041219 [in Ukrainian].

8. Postanova Kabinetu Ministriv Ukrainy vid 14 travnia 2015 r. No $281 \mathrm{v}$ redaktsii postanovy Kabinetu Ministriv Ukrainy vid 4 hrudnia 2019 r. No 1072 [Resolution of the Cabinet of Ministers of Ukraine of May 14, 2015 No 281 as amended by the Resolution of the Cabinet of Ministers of Ukraine of December 4, 2019 No 1072]. zakon.rada.gov.ua. Retrieved from https://zakon.rada.gov. ua/laws/show/281-2015-\%D0\%BF\#Text [in Ukrainian].

9. Postanova KMU «Pro zatverdzhennia Poriadku podannia deklaratsii pro provadzhennia hospodarskoi diialnosti u sferi kosmichnoi diialnosti» No198 vid 26.02.2020r. [Resolution of the Cabinet of Ministers of Ukraine «On approval of the Procedure for submitting a declaration on conducting economic activities in the field of space activities» 8198 of 26.02.2020]. zakon. rada.gov.ua. Retrieved from https://zakon.rada.gov.ua/laws/show/198-2020$\% \mathrm{D} 0 \% \mathrm{BF} \#$ Text [in Ukrainian].

10. Postanova KMU «Pro zatverdzhennia Poriadku vydachi (vidmovy u vydachi, anuliuvannia) dozvoliv na provadzhennia okremykh vydiv kosmichnoi 
Нормативно-правове забезпечення державного регулювання космічної галузі Украӥни diialnosti» No197 vid 26.02.2020r. [Resolution of the Cabinet of Ministers of Ukraine «On approval of the Procedure for issuance (refusal to issue, revocation) of permits for certain types of space activities» No197 from 26.02.2020]. zakon. rada.gov.ua. Retrieved from https://zakon.rada.gov.ua/laws/show/197-2020$\%$ D0\%BF\#Text [in Ukrainian].

11. Postanova Verkhovnoi Rady Ukrainy vid 11.12.2014 No26-VIII «Pro Prohramu diialnosti Kabinetu Ministriv Ukrainy» [Resolution of the Verkhovna Rada of Ukraine of 11.12.2014 No26-VIII «On the Program of Activities of the Cabinet of Ministers of Ukraine»]. zakon.rada.gov.ua. Retrieved from https:// zakon.rada.gov.ua/laws/show/26-19\#Text [in Ukrainian].

12. Rozporiadzhennia Kabinetu Ministriv Ukrainy No 238 vid 30 bereznia 2011 roku «Pro skhvalennia Kontseptsii realizatsii derzhavnoi polityky u sferi kosmichnoi diialnosti na period do 2032 roku» [Order of the Cabinet of Ministers of Ukraine No 238 of March 30, 2011 «On approval of the Concept of implementation of state policy in the field of space activities for the period up to 2032»]. zakon.rada.gov.ua. Retrieved from https://zakon.rada.gov.ua/laws/ show/238-2011-\%D1\%80\#Text [in Ukrainian].

13. Rozporiadzhennia Kabinetu Ministriv Ukrainy No 48-r vid 25 sichnia 2012 roku «Pro zatverdzhennia planu zakhodiv shchodo vykonannia Kontseptsii realizatsii derzhavnoi polityky u sferi kosmichnoi diialnosti na period do 2032 roku» [Order of the Cabinet of Ministers of Ukraine No 48-r of January 25, 2012 «On approval of the action plan for the implementation of the Concept of implementation of state policy in the field of space activities for the period up to 2032»]. zakon.rada.gov.ua. Retrieved from https://zakon.rada.gov.ua/laws/ show/48-2012-\%D1\%80\#Text [in Ukrainian].

14. Shemshuchenko, Yu.S., \& Semeniaka, V.V. (2019). Suchasnyi stan ta neobkhidnist reformuvannia kosmichnoho zakonodavstva Ukrainy [The current state and the need to reform the space legislation of Ukraine]. Chasopys Kyivskoho universytetu prava - Journal of Kyiv University of Law, 2, 9-16 [in Ukrainian].

15. Soroka, L.V. (2019). Poniattia derzhavnoho rehuliuvannia i derzhavnoho upravlinnia kosmichnoiu diialnistiu ta yikh rozmezhuvannia [The concept of state regulation and state management of space activities and their delimitation]. Naukovyi visnyk publichnoho ta pryvatnoho prava-Scientific Bulletin of Public and Private Law, 4, Vol. 2, 193-198 [in Ukrainian]. 
«Public Administration and Regional Development»

https://pard.mk.ua/index.php/journal

16. Ukaz Prezydenta Ukrainy «Pro optymizatsiiu systemy tsentralnykh orhaniv vykonavchoi vlady» vid 09.12.2010 r. No1085/2010 [Decree of the President of Ukraine «On optimization of the system of central executive bodies» dated 09.12.2010 No1085/2010]. zakon.rada.gov.ua. Retrieved from https://zakon.rada.gov.ua/laws/show/1085/2010\#Text [in Ukrainian].

17. Ukaz Prezydenta Ukrainy «Pro stvorennia Natsionalnoho kosmichnoho ahentstva Ukrainy» No117 vid 29.02.1992r. [Decree of the President of Ukraine «On the establishment of the National Space Agency of Ukraine» No117 of 29.02.1992]. zakon.rada.gov.ua. Retrieved from https://zakon.rada.gov.ua/laws/ show/117/92\#Text [in Ukrainian].

18. Ukaz Prezydenta Ukrainy vid 12.01.2015 No5/2015 «Pro Stratehiiu staloho rozvytku «Ukraina-2020» [Decree of the President of Ukraine of 12.01.2015 No5/2015 «On the Sustainable Development Strategy «Ukraine-2020»]. zakon.rada.gov.ua. Retrieved from https://zakon.rada.gov. ua/laws/show/5/2015\#Text [in Ukrainian].

19. Zakliuchnyi zvit pro rezultaty vykonannia Zahalnoderzhavnoi tsilovoi naukovo-tekhnichnoi kosmichnoi prohramy Ukrainy na 2013-2017 roky [Final report on the results of the implementation of the National Targeted Scientific and Technical Space Program of Ukraine for 2013-2017]. www.nkau.gov.ua. Retrieved from https://www.nkau.gov.ua/ua/activity/zvity-pro-diialnist [in Ukrainian].

20. Zakon Ukrainy Pro derzhavnu pidtrymku kosmichnoi diialnosti No 1559-III vid 16.09.2000 r. [Law of Ukraine On state support of space activities No 1559-III of 16.09.2000]. zakon.rada.gov.ua. Retrieved from https://zakon. rada.gov.ua/laws/show/1559-14\#Text [in Ukrainian].

21. Zakon Ukrainy Pro kosmichnu diialnist No 502/96-VR vid 15.11.1996 r. [Law of Ukraine On Space Activities No 502/96-VR of 15.11.1996]. zakon. rada.gov.ua. Retrieved from https://zakon.rada.gov.ua/laws/show/502/96$\% \mathrm{D} 0 \% \mathrm{~B} 2 \% \mathrm{D} 1 \% 80 \#$ Text [in Ukrainian].

22. Zakon Ukrainy Pro vnesennia zmin do deiakykh zakoniv Ukrainy shchodo derzhavnoho rehuliuvannia kosmichnoi diialnosti No 143-IX vid 02.10.2019r. [Law of Ukraine On Amendments to Certain Laws of Ukraine on State Regulation of Space Activities No 143-IX of October 2, 2019]. zakon. rada.gov.ua. Retrieved from https://zakon.rada.gov.ua/laws/show/143-20\#Text [in Ukrainian]. 
Відомості про авторів / Information about the Authors

Псюк Михайло Олександрович: Житомирський державний технологічний університет: вул. Чуднівська, 103, м. Житомир, 10005, Україна.

Mykhaylo Psiuk: Zhytomyr State Technological University, 103, Chudnivska str., Zhytomyr, 10005, Ukraine.

ORCID. ORG/ 0000-0003-3786-7081

E-mail: org_pmo@ztu.edu.ua

Сергіенко Лариса Василівна: Житомирський державний технологічний університет: вул. Чуднівська, 103, м. Житомир, 10005, Україна.

Larysa Sergiienko: Zhytomyr State Technological University, 103, Chudnivska str., Zhytomyr, 10005, Ukraine.

ORCID. ORG/ 0000-0003-3815-6062

E-mail: sergiienko.lv@gmail.com 